\title{
МІЖНАРОДНА ЕЛЕКТРОННА КОМЕРЦІЯ: ПЕРСПЕКТИВИ РОЗВИТКУ
}

Юрченко М. М., Костова Н. І.

Стаття присвячена міжнародній електронній комерції - продажу товарів через сайт електронної комерції покупцям в іноземних країнах. Оскільки поширення цифрових інструментів збільшує доступність Інтернету у всьому світі, будь-яка компанія може продавати через Інтернет, що полегшує міжнародну електронну комерцію. Для традиційних роздрібних торговців електронна комерція також може служити випробувальним полігоном для визначення того, чи будуть нові іноземні ринки успішними, перш ніж відкрити там фізичне місце розташування. Товари або послуги продаються на зовнішніх ринках через Інтернет-продажі та маркетинг. Сукупно обсяги продажів електронної комерції у всьому світі зросли на 276,9\% за останній відстежуваний період. Електронна комерція допомогла компаніям встановити ширшу присутність на ринку, забезпечивши дешевші та ефективніші канали розподілу своєї продукції чи послуг. Щоб не відставати, окремі продавці дедалі частіше беруть участь в операціях електронної комерції через власні персональні сайти. Зрештою, цифрові ринки, такі як eBay або Etsy, служать біржами, де багато покупців та продавців об'єднуються задля ведення бізнесу. Основними принципами товарної політики підприємств, що займаються бізнес-процесами в Інтернеті, мають бути такі: доцільно забезпечити електронний ринок безплатними товарами (послугами) з метою розширити аудиторію потенційних покупців вдосконаленого товару; з метою формування необхідного обсягу попиту на товари чи послуги в майбутньому бажано запропонувати зацікавленим клієнтам безкоштовно користуватися їхньою версією. Електронна комерція розуміється у кількох сенсах: вузькому (розглядається як комерційна діяльність лише Інтернет-провайдерами та виробниками інформаційних технологій), звуженому (ототожнюється з електронною комерцією, коли мова йде про купівлю-продаж фізичних, цифрових товарів, послуг, купонів та квитків через lнтернет) та широкому (усі можливі способи використання цифрового інформаційного простору та технологій для поширення ділової інформації, побудови взаємозв'язків між субринками та економічною діяльністю). Зі сказаного вище можна сказати, що електронна комерція є невід'ємною частиною електронного бізнесу, найбільш розвиненою, реалізованою у своїй галузі. А Інтернет-комерція - це напрям електронної комерції в їі вузькому розумінні, яке створює принципово нові можливості та орієнтоване на торгівлю з використанням інформаційних технологій та Інтернету. На думку авторів, «електронна комерція» - це специфічна частина електронного бізнесу, що включає зв'язки з громадськістю щодо купівлі-продажу товарів, послуг та інформації через Інтернет із використанням усіх інструментів, доступних в Інтернеті.

Ключові слова: міжнародна електронна комерція, Інтернет-стратегія, маркетингова стратегія, електронна комерція, Інтернет-середовище, Інтернет-послуги, електронний бізнес.

Yurchenko M. M., Kostova N. I. International electronic commerce: development prospects

The article is devoted to international e-commerce this is the sale of goods through an e-commerce site to buyers in foreign countries. As the proliferation of digital tools increases the worldwide availability of the Internet, any company can sell over the Internet, making international e-commerce easier. For traditional retailers, e-commerce can also serve as a testing ground for determining whether new foreign markets will be successful before opening a physical location there. Products or services are sold in foreign markets through Internet sales and marketing. Cumulatively, e-commerce sales worldwide will increase by $276.9 \%$ over the last monitored period. E-commerce has helped companies establish a broader market presence by providing cheaper and more efficient distribution channels for their products or services. Not to be outdone, individual merchants are increasingly engaging in e-commerce transactions through their own personal sites. Finally, digital markets like eBay or Etsy serve as exchanges where many buyers and sellers come together to conduct business. The main principles of the product policy of enterprises engaged in business processes on the Internet should be: it is advisable to provide the electronic market with free goods (services) in order to expand the audience of potential buyers of the improved product; in order to generate the required volume of demand for goods or services in the future, it is advisable to offer interested customers for free use of their version. E-commerce is understood in several senses - narrow (viewed as a com-

(๖) Юрченко М. М., Костова Н. І., 2020 
mercial activity only by Internet providers and information technology manufacturers), narrowed (identified with e-commerce when it comes to buying and selling physical, digital goods, services, coupons and tickets over the Internet) and broad (all possible ways of using digital information space and technologies to disseminate business information, build relationships between submarkets and economic activity). From the above, we can say that e-commerce is an integral part of e-business, the most developed, implemented in its field. And Internet commerce is a direction of e-commerce, its understanding in a narrow sense, which creates fundamentally new opportunities and is focused on trade using information technologies and the Internet. According to the authors, "e-commerce" is a specific part of e-business that includes public relations for the purchase and sale of goods, services and information over the Internet using all the tools available on the Internet.

Key words: international e-commerce, internet strategy, marketing strategy, e-commerce, internet environment, internet services, e-business.

Постановка проблеми та іï актуальність. Міжнародна електронна комерція - це незалежна можливість збільшення. Завдяки недавньому дослідженню, проведеному Flow Commerce, 67\% покупців в Інтернеті, що одягаються на 11 провідних світових ринках, здійснили транскордонні покупки за останні місяці.

Статистика свідчить, що глобальний ринок електронної комерції становить 2 трлн доларів у 2020 р., при цьому доходи в Китаї матимуть найбільші темпи зростання на рівні CAGR до $11,6 \%$ до 2024 року. За даними нашого дослідження, найбільша частота транскордонних покупців була у Бразилії, Австралії та Канаді.

Ця тенденція підтверджується в окремому звіті, що показує, що високий рівень транскордонного проникнення покупців через Інтернет у цих країнах, а також у Китаї та Мексиці. Тенденція транскордонних покупок, безумовно, не сповільнюється і продовжує набирати популярність.

У звіті «Глобальний ринок» прогнозується, що глобальна електронна комерція зросте майже на 20\% CAGR і сягне 18,89 трлн доларів до 2027 р. На це збільшення впливає низка факторів. Глобальний характер пошуку та використання пошукових систем сприяють відкриттю нових брендів та Інтернет-магазинів.

Проникнення мобільних пристроїв також мало впливає, сприяючи стимулюванню транскордонних покупок. Очікується, що продаж мобільної комерції на $25 \%$ зросте у 2020 р. порівняно з 2019 р., додатковий ріст відбудеться в 2021 р.
Завдяки 3 мільйонам користувачів смартфонів у всьому світі дедалі більше світових споживачів також здійснюють покупки через мобільні телефони, що дозволяє у сфері m-Commerce показувати вражаючий ріст. За допомогою мобільних пристроїв більше споживачів отримують доступ до платформи соціальних медіа.

3 недавніми глобальними правилами пандемії та карантину соціальні покупки набули поширення серед споживачів, саме тому вони становлять популярний канал для багатьох роздрібних торговців, які прагнуть розширення своєї глобальної клієнтської бази.

Аналіз останніх досліджень i публікацій. Одне з найважливіших завдань сучасної електронної комерції - це заміна традиційного механізму торгівлі між підприємствами. Саме вплив явища електронної комерції на світове застосування, що спричинило його трансформацію, та виникнення новітніх засобів взаємодії між учасниками ринку буде розглянуто у статті.

Правовий аспект використання інтернет-технологій був предметом вивчення Дж. Дункана, Т.Дж. Неймана, Дж. Форрестера. Можливості використання електронної комерції стали предметом дослідження А. Саммер, Інтернет-технологій - Л. Фріда та М. Лінднера.

Метою статті $\epsilon$ дослідження регулювання електронної комерції на сучасному етапі, аналіз теоретичних засад та головних напрямів становлення і розвитку міжнародного підходу в електронній комерції.

Виклад основного матеріалу. За умови правильної глобальної політики $\epsilon$ змога розкрити нову еру «інклюзивної торгівлі»: ту, в якій усі компанії незалежно від розміру, сектору чи місцезнаходження можуть отримати вигоду від рівного доступу до глобальної торгової системи. Інтернет-зміни у складі, характері та швидкості світової торгівлі посилюють політичні протиріччя як в Інтернеті, так і щодо доставки електронної комерції.

Ще однією передумовою успіху та життєздатності електронної комерції $\epsilon$ здатність інформації вільно та ефективно перетинати кордони, не обмежуючись технічними бар'єрами чи антиконкурентними вузькими місцями. Роздроблені національні правила щодо даних та доступності Інтернет-інформації дедалі частіше виступають головною перешкодою для торгівлі.

По-перше, Інтернет посилив інтерес до міжнародного приватного права та альтернативного вирішення спорів. Низькі економічні бар'єри для 
входу в Інтернет зумовлюють участь у торгівлі та політиці невеликих суб'єктів господарювання та приватних осіб, які не можуть дозволити собі безпосередню участь на багатьох традиційних ринках та політичних аренах. Ці низькі бар'єри для в'їзду та значна участь приватних осіб та малих підприємств також сприяють збільшенню частоти дрібних операцій.

Коли витрати на врегулювання суперечок $\epsilon$ високими, як і для традиційних адміністративних та судових процедур, трансакційні витрати на вирішення спорів загрожують поглибити вартість базової операції, що означає, з одного боку, те, що жертви рідше вимагають підтвердження своїх прав, з іншого - те, що суб'єкти та передбачувані правопорушники можуть зіткнутися з судовими витратами, які перевищують переваги їх пропонування товарів та послуг на нових електронних ринках.

Щоб усвідомити потенціал участі малих підприємств та фізичних осіб та дрібних операцій, необхідно зменшити витрати на вирішення спорів.

По-друге, географічна відкритість електронної комерції робить більш імовірними трансакції між сторонніми людьми.

Відсутність неформальних засобів розвитку довіри, на кшталт регулярних покупок у місцевій книгарні, означає, що як торговцям, так і споживачам буде заборонено займатися комерцією, якщо в них не буде певної допомоги, якщо угода піде на погіршення.

Має бути доступна якась прийнята форма вирішення суперечок, щоб встановити необхідну впевненість для комерції взагалі.

Щоб електронна комерція та політичний дискурс процвітали в Інтернеті, треба розробити та застосувати нові форми альтернативного вирішення спорів. Хоча велика частина відповідальності за креативний дизайн та практичне розгортання залежить від приватної ініціативи, а не урядових доручень, також варто звернути увагу на позицію приватного регулювання у всеосяжній законодавчій базі.

У всьому світі швидкість цих транзакцій дає змогу доходу, отриманому від операцій електронної комерції, бути дуже прибутковим для продавця електронної комерції.

Компанії, які впроваджують інструменти електронного бізнесу у свою діяльність, отримують низку конкурентних переваг шляхом зменшення витрат часу i коштів на пошук, збір і обробку інформації.

Перед ними відкриваються нові ринки і сфери діяльності, спрощується налагодження збуту та логістики, стають доступними високоефективні методи залучення нових та підвищується рівень обслуговування наявних клієнтів із можливістю їх підтримки.

На сучасному етапі електронна комерція посіла провідне місце поміж перспективних напрямів нормотворчо-правової діяльності СО Т, можна виділити низку конкретних напрямів, а саме: зниження бар'єрів у торгівлі товарами інформаційної технології (комп'ютери, телекомунікаційне обладнання, наукові прилади, програмне забезпечення, мікропроцесори тощо); розробка нових правових аспектів електронної торгівлі (наприклад, ідентифікація підпису під документами, захист конфіденційності, ідентичність інформації й документів, а також товарів і послуг, переданих електронним шляхом, захист авторських прав та суміжних прав); митне й податкове оподаткування товарів і послуг, які передаються електронним шляхом, насамперед, через систему мережі Інтернет [1]; електронна торгівля припускає передання інформації, продуктів або послуг для продажу, наприклад, електронним шляхом (експортовані книги, програмне забезпечення тощо).

Так, в умовах сучасних світових тенденцій визначаються нові пріоритети та чинники впливу на розвиток бізнесу. Виникає потреба визначити місце Інтернет-стратеегій у класифікації маркетингових стратегій. За критерієм «маркетингові можливості» можна виокремити стратегії підтримки конкурентних переваг - як наміри щодо розвитку інновацій комплексу маркетингу, управління маркетинговими інноваціями та Інтернет-технологіями.

Виникають нові моделі бізнесу в межах Інтернет-системи під впливом глобальних змін у роздрібній торгівлі, інтенсифікації галузевої конкуренції, швидкості нових досягнень. Підприємство стає конкурентоспроможним, якщо його споживачі беруть участь в електронних торгах.

Конкуренція із зони виробництва концентрується у сферу просування послуг (продукції) та споживання. Інтернет-технології зумовлюють конкурентні переваги для потенційних споживачів, конкретних підприємств та менеджерів із маркетингу.

Для онлайнових служб характерні такі переваги Інтернет-послуг потенційним споживачам: замовлення товарів у будь-який час і з будь-якого місця; можливість вивчення та ознайомлення з ціною, якістю, терміном, наявністю в продажі; об'єктивність вибору покупки. 
Конкурентні переваги, що надають онлайнові служби менеджерам із маркетингу: інформація про стан ринкової ситуації; більш дешева Інтернет-реклама; інтерактивний режим взаємовідносин із споживачами; можливість визначення кількості звернень до сайту фізичних та юридичних осіб.

Переваги для конкретних підприємств: можливості освоєння нових сегментів ринку; доступність для споживачів, що сприяє залученню нових споживачів; швидка реакція на потреби споживачів та поведінку конкурентів; надання клієнтам інформаційних послуг через Інтернет; зниження витрат на виробництво та продажу товарів і послуг шляхом зниження транзакційних витрат.

Організація діяльності підприємства в Інтернеті вимагає насамперед визначення перспектив. Добре окреслена перспектива, стратегія - це уявний образ бажаного результату, найважливіша передумова успіху будь-якої компанії.

Вироблення стратегії означає правильну оцінку становища компанії та ії конкурентів на ринку, розробку основного напряму діяльності на кілька років уперед і пошук шляхів досягнення поставлених цілей.

Цей процес дуже важливий для функціонування в масштабах нової віртуальної економіки. На відміну від традиційної економіки, де контроль каналів збуту здійснюється підприємством, в Інтернеті це контролюють споживачі: вони визначають попит на вдосконалену продукцію й очікують на індивідуальне обслуговування.

Крім того, в Інтернеті будь-які процеси відбуваються дуже динамічно, тому традиційні методи планування не можуть бути застосовані; стратегічні плани, в тому числі маркетингові, у цьому випадку придатні лише для коротких періодів часу.

Інтернет-середовище - це мінливе економічне середовище, що піддається впливу технологічних змін. Стратегічну практику тут неможливо прогнозувати надовго.

Нині персоналізація $€$ основним словом у галузі цифрової електронної комерції, i, ймовірно, вона залишатиметься актуальною. Одна 3 найпопулярніших тенденцій електронної комерції також висвітлює кризу коронації, з огляду на те, що підприємства намагаються утримати своїх клієнтів та додати ще кількох.

Персоналізація домашніх сторінок, показ персоналізованих продуктів на основі звичок покупця споживача та показ нещодавно переглянутих ними товарів - це деякі способи запропонувати налаштування на вебсайтах.
Багато модних вебсайтів широко використовують персоналізацію як ключову тенденцію, що виникає в електронній комерції, щоб зробити стрічку користувачів більш креативною та зручною, щоб забезпечити їм персоналізований досвід клієнтів.

Підприємства електронної комерції дуже часто намагаються запропонувати щось нове для своїх клієнтів. Це може бути комбінація додавання нових функцій, пропонування нового асортименту або навіть нового досвіду покупок на вебсайті.

Однак для конкурентоспроможності важливо швидко реагувати на зміни на ринку та пришвидшити випуск продуктів - це одна з основних тенденцій електронної комерції 2020 р.

Після випуску продукту аудиторію потрібно ознайомити з ним за допомогою цифрових партнерств та рекламних акцій.

Наприклад, маркетинг для інфлюенсерів - це сильний прогрес у напрямі швидшого та вищого охоплення. Можливість швидко створювати відповідні продукти, а також однаково швидко їх просувати за відповідними каналами суттєво сприятиме збільшенню популярності та продажів бренду.

Висновки. Можливо, найгірші наслідки нинішньої ситуації проходять повз, але наступні кілька місяців зумовлюватимуть питання антикризового управління та створюватимуть виклики перед галуззю цифрової торгівлі. Тим не менше технологічні інновації та тенденції електронної комерції 2020 р. можуть суттєво допомогти в боротьбі з проблемою та йти до стратегії відродження.

\section{Література}

1. UNCITRAL Model Law on Electronic Signatures with Guide to Enactment 2001. United Nations publication. URL: https://www.uncitralorg/pdf/english/texts/ electcom/ml-elecsig-e.pdf.

Юрченко М. М., кандидат політичних наук, доцент, завідувач кафедри конституційного та міжнародного прав одеського державного університету внутрішніх справ

Костова Н. І., кандидат юридичних наук, старший викладач кафедри, конституційного та міжнародного права Одеського державного університету внутрішніх справ 